\title{
A Study of the Physico-Chemical Characteristics of Raw, Filtered, and Treated Water at A Water Treatment Plant in Shebin El-Kom, Egypt.
}

\author{
Elsayed A. Khallaf ${ }^{1}$; Mansour Galal ${ }^{1}$; S. El-Sbbagh ${ }^{2}$ and Noura M. Nabet ${ }^{1}$ \\ 1- Zoology Dept., Faculty of Science, Minofia University, Egypt. \\ 2- Botany Dept, Faculty of Science, Minufeya University, Egypt.
}

\begin{abstract}
Potable water is a necessity for safe and better quality. In Egypt, this is no exception, and consequently, this study investigated the physico-chemical properties of raw, and treated water in Shebin El-Kom Water Treatment Plant. As indicated, here in this study, a number of parameters, namely Ammonia, Nitrates, and Chlorides, were observed to occur in water after treatment. Furthermore, Chlorides, Iron, Nitrites, TDS, Mn, and Mg, might occur in treated water at certain times of the year. Those parameters proved to be indicator for physico-chemical characteristics. Accordingly, a recommendation is presented.
\end{abstract}

Keywords: Physico-chemical parameters, Potable water, Water-treatment

\section{INTRODUCTION}

Safe drinking-water is a basic need for human development, health and wellbeing, and because of this it is an internationally accepted human right (WHO, 2001; Thompson et al., 2007). The purpose of water treatment is to remove pathogens, toxic chemicals, particles, and aesthetic contaminants from raw water. (Logsdon et al., 1999).

There are various treatment methods available for making water safe and appealing to consumers. These methods depend primarily on the characteristics of raw water (Wiesner and Klute, 1997). As water is drawn from many ground and surface sources, it has diverse qualities which, in turn, dictate the type of treatment, the degree of treatment and, to a large extent, the quality of the treated water (Hofkes, 1983; ElMasry et al., 2004).

A wide variety of water treatment processes have been developed for production of safe potable water. Conventional treatment is the most widely used method to control microbial and turbidity levels in surface supplied drinking water (USEPA, 1990; Haas, 1999; El-Masry et al., 2004). The main objective of conventional water treatment is to provide drinking water to the consumer that is biologically stable, and as such, is both aesthetically pleasing and does not present a measurable health risk to the consumer (Långmark, 2004).

Measuring the physico-chemical characters of water; such as temperature, electrical conductivity, total solids, $\mathrm{pH}$, nutrient salts, phosphate, sulfate, ammonianitrogen, calcium, iron, chloride, magnesium, zinc, nitrate and fluoride contents of the waters is important to investigate both water quality and ecological variations of the water body (WHO, 1996; Ayoko et al., 2007), and the subsequent treatment.

Consequently, this study was planned in order to make an investigation concerning the efficiency of the water treatment process in Shebin El-Kom Water Treatment Plant. This included quantitative analysis of both influent and effluent water physico- chemical parameters and their interaction. 


\section{MATERIAL AND METHODS}

\section{Study Area}

Water Treatment Plant at Shebeen Alkoom is located South of the city and feeds the western side of the city (Fig 1).

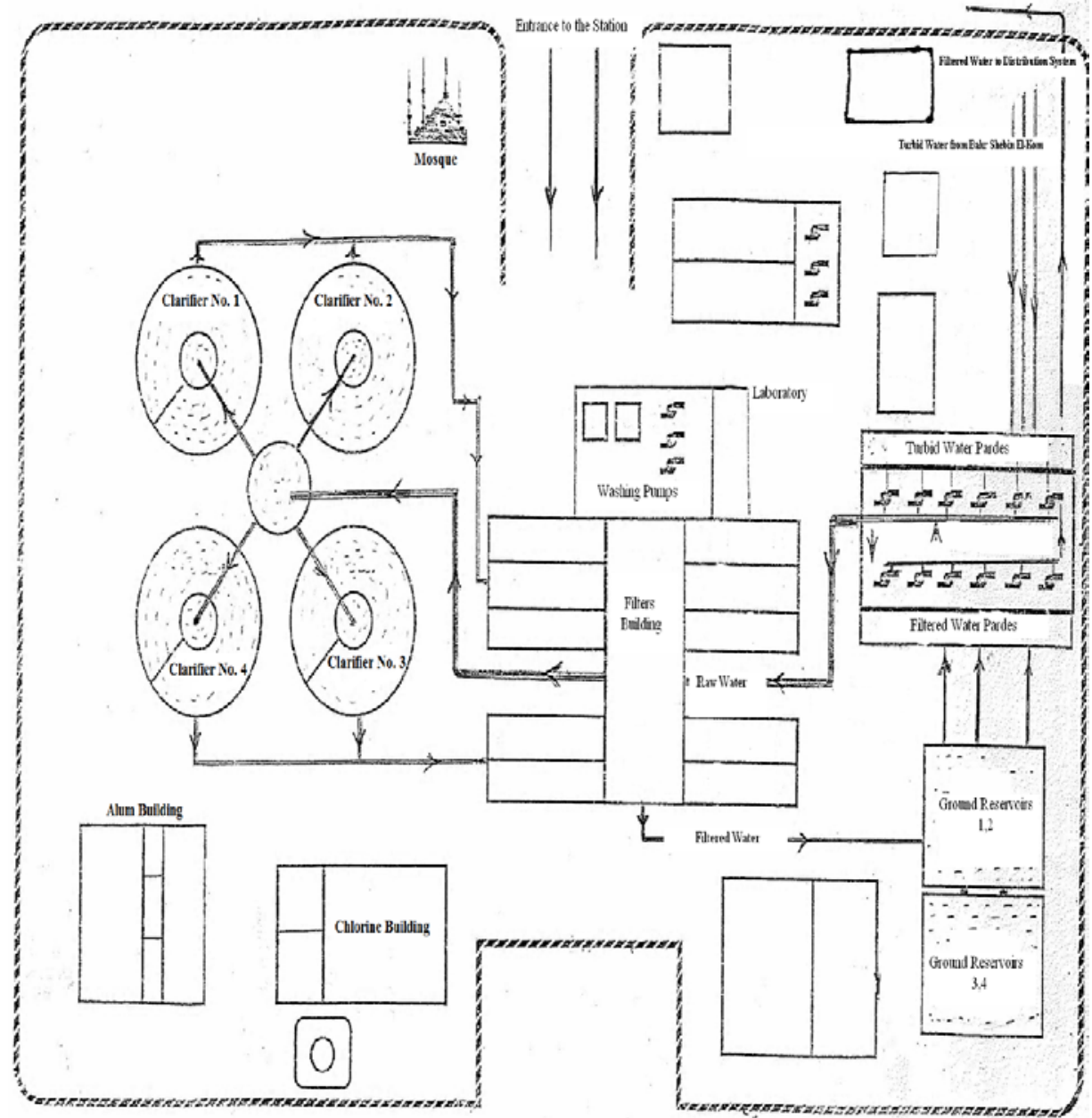

Fig. 1: Diagram of Shebeen Alkoom Water Treatment Plant

\section{Sample Determinations and Collection Procedures}

Water samples for microbiological analysis were collected in one liter glass bottles containing $1 \mathrm{ml}$ of $3 \%$ freshly prepared sodium thiosulphate solution $\left(\mathrm{Na}_{2} \mathrm{~S}_{2} \mathrm{O}_{3}\right)$, to neutralize the residual chlorine. The samples were preserved in an ice box during transportation (APHA, 1995), to the laboratory, three times monthly during a period from November 2008 to November 2009 and examined within 6 hours of collection.

\section{Physical Parameters}

\section{Temperature}

Temperature of water was measured using a calibrated thermometer.

\section{Electrical Conductivity (EC) and Total Dissolved Solids (TDS)}

EC was measured at $25^{\circ} \mathrm{C}$ as standard temperature by using CON 6000 Bench Electrical Conductivity Meter (model No. EPA-30IDAN-9, Eutech Instruments, Singapore), and expressed as $\mu \mathrm{mhos} / \mathrm{cm}$. Total dissolved solids of the collected water samples were expressed as $\mathrm{mg} / \mathrm{L}$. 


\section{Turbidity}

Turbidity is measured as "Nephelometric turbidity units" (NTU) by using turbidity meter (PcH019054, Germany).

\section{Chemical parameters}

\section{Hydrogen Ion Concentration (pH)}

The $\mathrm{pH}$ values were determined by the use of Bench-Top $\mathrm{pH} /$ Ion Meter (Model 6500, china).

\section{Total Alkalinity (Carbonate and Bicarbonate)}

As the $\mathrm{pH}$ value for collected samples was lower than 8.3, then total alkalinity was determined as carbonate only where it was measured by applying a titration method ( $0.02 \mathrm{NH}_{2} \mathrm{SO}_{4}$ with methyl orange as indicators ) APHA (1992). The results are expressed as mg ca co3/ L.

\section{Chloride}

The recommended titration procedure involves adding silver nitrate $\left(\mathrm{AgNo}_{3}\right)$ to the sample which reacts with chloride ions to form a white precipitate of silver chloride, then in the presence of the potassium chromate as indicator, adding excess silver nitrate forms a reddish precipitate of silver chromate (APHA, 1992). The chloride content of water was then calculated and expressed as mg/L.

\section{Determination of Hardness (Calcium and Magnesium)}

Calcium and magnesium in water samples were determined using EDTA (Ethylene diamine tetra acetate) Titrimetric method according to APHA (1992).

\section{Dissolved Oxygen (DO)}

The oxygen content of the water samples was measured by SB70D DO Benchtop Meter S/NDO 0800, U.S.A. and expressed as mg/L.

\section{Sulphate}

Sulphate ion was measured by using assay colorimetric kits (Spectrophotomer Hach, DR5000, Germany) according to the manufactures' protocols. The results were expressed as $\mathrm{mg} / \mathrm{L}$.

\section{Other Chemical Parameters}

Ammonia (NH3), nitrite (No2), nitrate (No3), phosphate (Po4), silica (Si), iron (Fe), manganese (Mn) and fluoride (FI) contents were determined using assay colorimetric kits (HANNA instrument, C200 Multiparameter Ion Specific Meter, Hungary) according to the manufacture's protocols. The results were expressed as $\mathrm{mg} / \mathrm{l}$.

\section{RESULTS AND DISCUSSION}

\section{Seasonal Variations of Physio-Chemical Parameters}

As indicated in Table 1 various parameters, however, significant parameters which are found to be critical to drinking water, are shown and discussed as follows:

\section{Total Dissolved Solids (TDS)}

The Seasonal variations of total dissolved solids indicated that maximum value $247.9 \mathrm{mg} / \mathrm{L}$ was recorded during Spring at raw water and the minimum values 195.5 was obtained in Autumn. On the other hand, TDS fluctuation was varying in the range of 200.3 in Spring to $253.7 \mathrm{mg} / \mathrm{L}$ in Winter in filtered water. While their values ranged between $202.3 \mathrm{mg} / \mathrm{l}$ in Winter, to 248.3 in Spring, for treated water. However, TDS in tap water was found to have a lower value of $196.4 \mathrm{mg} / \mathrm{l}$ in Spring, but their higher value of 294.7 in Winter. 
Table 1: Seasonal Variations of Physio-chemical Parameters in different Stages (Raw, Filtered and Treated Water) at Shebeen Alkoom Water Treatment Plant, and Tap Water.

\begin{tabular}{|c|c|c|c|c|c|c|c|c|c|c|c|c|c|c|c|c|c|}
\hline \multirow[t]{2}{*}{ Parameters } & \multicolumn{4}{|c|}{ Raw Water } & \multicolumn{4}{|c|}{ Filtered Water } & \multicolumn{4}{|c|}{ Treated Water } & \multicolumn{4}{|c|}{ Tap Water } & \multirow{2}{*}{$\begin{array}{r}* \star \\
\text { MPL }\end{array}$} \\
\hline & 离 & 觜 & $\begin{array}{l}\text { 莺 } \\
\text { 范 }\end{array}$ & 目 & 章 & 皆 & 章 & 目 & 总 & 皆 & 丞 & 署 & 害 & 照 & 龺 & 罯 & \\
\hline $\begin{array}{l}\text { Termerature } \\
{ }^{\circ} \mathrm{C}\end{array}$ & 17.78 & 22.84 & 28.33 & 24.30 & 17.78 & 22.84 & 28.33 & 24.30 & 17.78 & 22.84 & 28.33 & 24.30 & 17.78 & 22.84 & 28.33 & 24.30 & -- \\
\hline$\overline{\mathrm{PH}}$ & 7.43 & 7.87 & 7.27 & 7.79 & 7.29 & 7.75 & 693 & 7.41 & 7.27 & 7.66 & 695 & 751 & 7.05 & 7.35 & 7.07 & 7.48 & $\begin{array}{l}6.5- \\
8.5\end{array}$ \\
\hline $\begin{array}{l}\text { Tubility * } \\
\text { (NTU) }\end{array}$ & 4.71 & 10.09 & 8.62 & 10.21 & 1.81 & 5.06 & 1.13 & 3.97 & 1.40 & 2.27 & 0.71 & 2.33 & 1.74 & 9.22 & 1.50 & 2.55 & $<5$ \\
\hline Chboride mg/L & 39.67 & 48.22 & 27.44 & 48.08 & 30.50 & 47.89 & 30.00 & 64.42 & 36.00 & 49.06 & 31.56 & 56.04 & 41.67 & 47.78 & 31.44 & 66.83 & 250 \\
\hline $\begin{array}{l}\text { Allalinity } \\
\mathrm{mgCaC} O \mathrm{~B} / \mathrm{L}\end{array}$ & 181.33 & 174.11 & 155.78 & 175.67 & 171.83 & 168.78 & 132.00 & 153.83 & 155.33 & 159.56 & 135.78 & 161.33 & 155.67 & 162.11 & 119.56 & 164.33 & -- \\
\hline $\begin{array}{l}\text { Magnesium } \\
\mathrm{mg} / \mathrm{L}\end{array}$ & 23.33 & 26.48 & 15.79 & 24.60 & 22.93 & 18.40 & 2019 & 31.80 & 19.30 & 22.96 & 20.48 & 25.96 & 20.74 & 18.03 & 12.80 & 27.07 & -- \\
\hline $\begin{array}{l}\text { Magnesium } \\
\text { Hardness } \\
\text { mo/L }\end{array}$ & 91.67 & 110.33 & 65.78 & 10250 & 89.33 & 76.67 & 85.61 & 132.50 & 80.67 & 95.67 & 85.33 & 10817 & 8617 & 75.11 & 5333 & 112.50 & 150 \\
\hline Calcium mo/L & 37.78 & 32.71 & 37.16 & 34.18 & 31.68 & 32.71 & 47.02 & 28.40 & 33.47 & 26.58 & 47.20 & 27.87 & 32.83 & 30.27 & 31.02 & 29.87 & -- \\
\hline $\begin{array}{l}\text { Calcium } \\
\text { Hardness } \\
\mathrm{mg} / \mathrm{L}\end{array}$ & 91.67 & 81.78 & 92.89 & 90.50 & 81.00 & 81.78 & 117.56 & 80.67 & 83.67 & 66.44 & 118.00 & 79.00 & 8450 & 75.67 & 77.56 & 82.67 & 350 \\
\hline $\begin{array}{l}\text { Total } \\
\text { Hardness } \\
\mathrm{mg} / \mathrm{L}\end{array}$ & 190.00 & 192.11 & 158.67 & 195.33 & 174.17 & 158.44 & 136.00 & 210.25 & 164.33 & 162.11 & 136.67 & 185.89 & 169.33 & 157.44 & 130.89 & 193.57 & 500 \\
\hline T.D.S.mg/L $\mathrm{L}^{\star \star}$ & 203.23 & 247.99 & 22455 & 195.53 & 200.30 & 253.76 & 217.98 & 236.11 & 202.33 & 248.32 & 230.48 & 214.62 & 196.43 & 294.72 & 221.09 & 213.35 & 500 \\
\hline $\begin{array}{l}\text { Conductivity } \\
\text { umhos } / \mathrm{cm}\end{array}$ & 346.00 & 481.37 & 380.20 & 38198 & 337.50 & 490.07 & 375.78 & 463.35 & 33517 & 485.47 & 393.89 & 41993 & 336.33 & 39519 & 381.03 & 425.40 & $\begin{array}{c}<000 \\
200\end{array}$ \\
\hline $\begin{array}{l}\text { Manganese } \\
\mathrm{mg} / \mathrm{L}\end{array}$ & 0.01 & 012 & 0.09 & 1.44 & 0.00 & 0.10 & 0.01 & 2.38 & 0.00 & 0.05 & 0.00 & 2.42 & 0.00 & 0.97 & 0.00 & 219 & 0.05 \\
\hline Iron $\mathrm{mg} / \mathrm{L}$ & 015 & 018 & 0.07 & 0.23 & 0.00 & 0.02 & 0.11 & 0.11 & 0.00 & 0.03 & 0.07 & 011 & 0.35 & 0.78 & 0.05 & 0.47 & 0.3 \\
\hline Sulphate $\mathrm{mg} / \mathrm{L}$ & 25.37 & 2611 & 27.39 & 21.38 & 25.72 & 31.51 & 3699 & 28.38 & 31.75 & 34.06 & 37.33 & 26.25 & 35.48 & 63.71 & 52.77 & 34.25 & 250 \\
\hline Silica mg/L & 1.80 & 1.70 & 193 & 1.82 & 1.60 & 1.81 & 1.85 & 1.53 & 1.31 & 1.37 & 1.71 & 1.39 & 1.43 & 1.31 & 1.97 & 1.60 & 28 \\
\hline Nitrite mo/L & 13.86 & 991 & 16.02 & 16.05 & 1116 & 6.46 & 1393 & 12.40 & 14.66 & 5.90 & 12.63 & 9.01 & 24.61 & 6.31 & 21.36 & 11.84 & 1 \\
\hline Nitrate $\mathrm{mg} / \mathrm{L}$ & 400 & 1.54 & 5.48 & 492 & 3.80 & 1.33 & 4.88 & 3.14 & 351 & 0.94 & 5.01 & 2.42 & 5.28 & 191 & 5.56 & 5.45 & 10 \\
\hline Fluoride $\mathrm{mg} / \mathrm{L}$ & 0.73 & 0.61 & 0.52 & 0.76 & 0.64 & 0.50 & 0.51 & 0.66 & 0.64 & 0.62 & 0.77 & 0.60 & 0.71 & 092 & 0.80 & 1.06 & 2 \\
\hline $\begin{array}{l}\text { Ammonia } \\
\mathrm{mg} / \mathrm{L}\end{array}$ & 0.04 & 0.04 & 018 & 0.03 & 0.03 & 0.05 & 0.05 & 0.03 & 0.05 & 0.47 & 0.01 & 0.00 & 018 & 0.08 & 0.54 & 0.05 & 218 \\
\hline $\begin{array}{l}\text { Dissolved } \\
\text { Oxygen } \mathrm{mg} / \mathrm{L}\end{array}$ & 7.65 & 708 & 8.31 & 9.31 & 6.45 & 7.25 & 6.81 & 8.34 & 6.84 & 7.88 & 715 & 8.27 & 6.85 & 8.23 & 6.35 & 8.59 & -- \\
\hline $\begin{array}{l}\text { Phosphate } \\
\mathrm{mg} / \mathrm{L}\end{array}$ & 0.48 & 0.28 & 0.58 & 011 & 0.55 & 0.26 & 0.24 & 0.08 & 0.51 & 0.40 & 0.01 & 0.03 & 1.23 & 2.40 & 0.54 & 0.26 & 0.1 \\
\hline
\end{tabular}

* NTU: Nephelometric turbidity units

** T.D.S.: Total dissolved solids

***MPL: Maximum Permissible Limits according to Environmental Protection Agency (2010).

TDS are considered a measure of the total ionic concentration in water (Welcomme, 1985). This is conspicuous, since a highly significant correlation between TDS and conductivity is predicted in this study ( $r=0.84, \mathrm{p}<0.01$; Fig 2 ).

Fig. 2. Conductivity vs. Turbidity

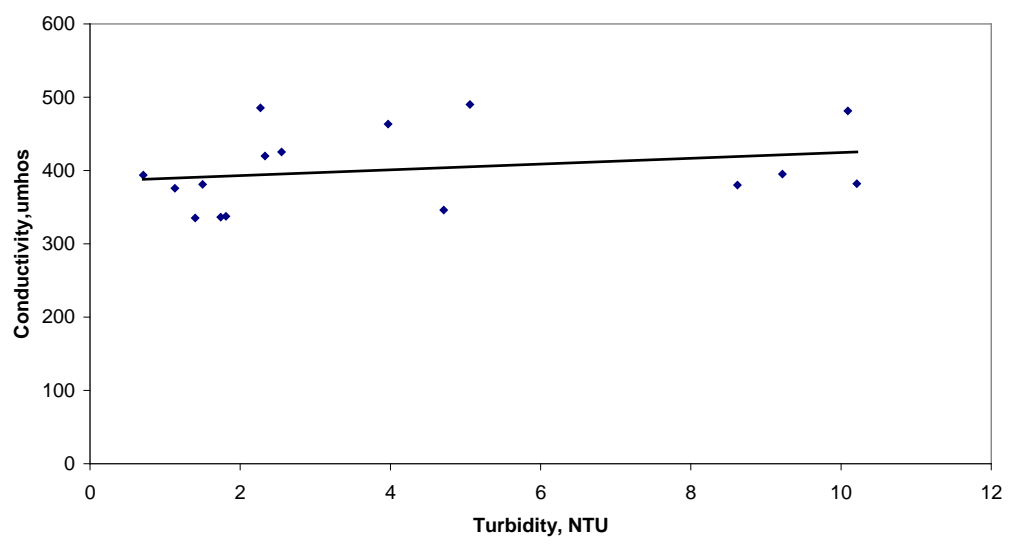


In the present work, the dissolved solids reached a maximum count during Spring, as reported earlier by Elewa and Authman (1991). On the other hand, the results are in contrast with the findings of Abd El Satar (1994) who reported that their maximum values in River Nile water, at the barrage, were recoded during Winter season.

\section{Electrical Conductivity (EC)}

The electrical conductivity in raw water stage fluctuated between the minimum value of $346 \mu \mathrm{mhos} / \mathrm{cm}$ measured in Winter and to the maximum value of 481.3 $\mu \mathrm{mhos} / \mathrm{cm}$ in Spring. In filtered water, the higher value of $490 \mu \mathrm{mhos} / \mathrm{cm}$ was recorded during Spring and the lower value of $337.5 \mu$ mhos/cm was recorded during Winter. In treated water, the maximum value of $485.4 \mu \mathrm{mhos} / \mathrm{cm}$ was obtained in Spring and the minimum value of $335.1 \mu \mathrm{mhos} / \mathrm{cm}$ was obtained in winter. However, in tap water the maximum value of $425.4 \mu \mathrm{mhos} / \mathrm{cm}$ was obtained during Autumn and the minimum value of $336.3 \mu \mathrm{mhos} / \mathrm{cm}$ was obtained during Winter.

The observed results of that parameter are in agreement with the findings of Elewa and Authman (1991) and Abd Elsatar (1994), but only in Winter. On the other hand, they disagreed with the present results, that the maximal value of EC was recorded on Spring, where they reported that the higher value of EC was recorded during Autumn in Nile water at El-kanater El-Khyria. These EC fluctuations may be due to the increases in salinity and total dissolved solids (APHA, 1985).

\section{Hydrogen Ion Concentration (pH)}

Hydrogen ion concentration fluctuated in the ranges of 7.27-7.87, 6.93-7.75, 6.95-7.66, and 7.05-7.48 in raw water, filtered water, treated and tap water respectively. With the minimum values in Summer and maximum values in Spring for raw water, filtered water and treated while for tap water, the maximum value was obtained in Autumn and minimum value in Winter.

In this investigation, there was a minor variation in the $\mathrm{pH}$ values, which are in accordance with the results obtained with the Nile system in Egypt (Ahmed, 1983; Zidan, 1983). The present results showed that $\mathrm{pH}$ values in Summer season were lower than the corresponding values on Winter and other seasons, and these agreed with the findings of Birhanu (2007), who reported that $\mathrm{pH}$ values were relatively high in Winter compared to Summer.

\section{Alkalinity}

The seasonal value of bicarbonate concentrations for different stages are illustrated as follows: In raw water, the bi-carbonate values ranged from a minimum of $155.78 \mathrm{mg} / \mathrm{l}$ recorded during Summer to a maximum of $181.33 \mathrm{mg} / \mathrm{l}$ recorded during Winter. In Filtered water, the bicarbonate value ranged form a minimum of $132 \mathrm{mg} / \mathrm{l}$ recorded during Summer to a maximum of $171.33 \mathrm{mg} / \mathrm{l}$ recorded during Winter. On the other hand, in treated water, the bicarbonate value ranged for a minimum of $135.78 \mathrm{mg} / \mathrm{l}$ recorded during Summer, to a maximum $161.33 \mathrm{mg} / \mathrm{l}$ recorded during Autumn, while in tap water the higher value of $164.33 \mathrm{mg} / \mathrm{l}$ recorded during Autumn and lower value of $119.56 \mathrm{mg} / \mathrm{l}$ caco3/recorded in Summer. The seasonal average of bicarbonate values in raw water samples was obviously low during Summer season, and a marked increase was found during Winter season.

This is in agreement with the previous work on the Nile water by Sayyah et al. (1988) Elewa et al. (1995) and the results of Helal (1981) on Damiatta branch of the Nile. On the other hand, the present results are in contrast to the findings of Elewa and Authamn (1991) in Bahr Shebin Cancal, who reported that the total Alkalinity has its maximum during Autumn. 


\section{Chloroisty}

The seasonal chloride ion concentrations varied from a minimum value of 27.44 $\mathrm{mg} / \mathrm{l}$ recorded during Summer at Raw water to a maximum value of $48.22 \mathrm{mg} / \mathrm{l}$ recorded in Spring. On the other hand, the variations of chloride ion concentrations fluctuated in the range of 30 to $64.42 \mathrm{mg} / \mathrm{l}, 31.56$ to $56.04 \mathrm{mg} / \mathrm{l}$ and 31.44 to 66.83 $\mathrm{mg} / \mathrm{l}$ for filtered, treated and tap water respectively with the higher values in Autumn and the lower values in the Summer. The present results of the Chloroisty indicate that the general seasonal average trend was characterized by a progressive increase during Autumn and Spring seasons but decrease during Summer and Winter seasons. These results are in agreement with those of Elewa and Authman (1991) in Bahr Shebin, and Elwa et al. (1995) in Nile water who found that Chlorosity of water was minimum during Summer. High chloride content in inland waters may be an indication of pollution (Michael, 1986; APHA, 1992). The present results showed a positive correlation between Chlorides and Alkalinity ( $r=0.63, \mathrm{p}<0.05$; Fig 3). This is due to the role of alkalinity for neutralizing acidity of aquatic habitat.

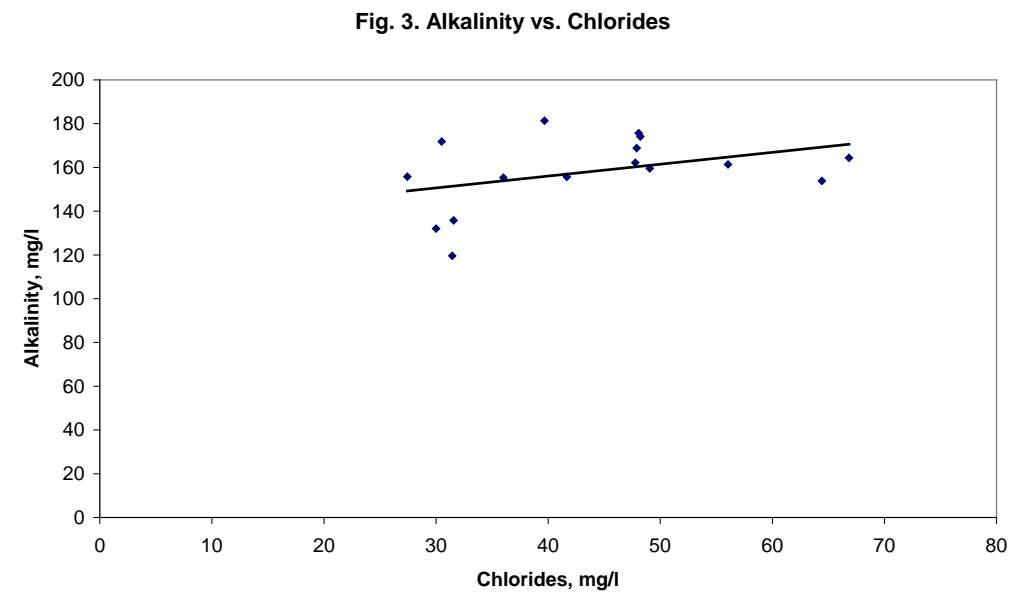

\section{Calcium}

In raw water, the calcium concentrations ranged between the minimum value of $32.71 \mathrm{mg} / \mathrm{L}$ recorded in Spring and the maximum value of $37.78 \mathrm{mg} / \mathrm{l}$ recorded in Winter. While in filtered water, calcium concentration ranged from the lower value of $28.40 \mathrm{mg} / \mathrm{l}$ obtained in Autumn to the higher value of $47.02 \mathrm{mg} / \mathrm{l}$ obtained in Summer. In treated water, calcium concentrations ranged between the minimum value of 26.58 in Spring and the maximum value of $47.20 \mathrm{mg} / \mathrm{l}$ recorded in Summer. While in tap water, it ranged from 29.87 to $32.83 \mathrm{mg} / \mathrm{l}$ in Autumn and Winter respectively.

In the present study, the seasonal average trend was characterized by progressive increase during Winter and Summer seasons and decrease during Spring and Autumn seasons. The present results for calcium are in contrast to these of Elewa and Mahdi (1988), in Nile water who found that Calcium was minimum on Winter and maximum on Summer.

\section{Turbidity}

The turbidity content in raw water ranged between the minimum value of 4.71 in Winter and the maximum value of $10.21 \mathrm{mg} / \mathrm{l}$ recorded in Autumn. In filtered water, the turbidity ranged between 1.13 to $5.06 \mathrm{mg} / \mathrm{l}$ recorded in Summer and Spring respectively. In treated water the value ranged between 2.33 to $0.71 \mathrm{mg} / \mathrm{l}$ recorded in Summer and Autumn respectively, while in tap water, it ranged between 1.50 to 9.22 $\mathrm{mg} / \mathrm{l}$ recorded in Summer and Spring respectively. 
However, in raw water, a significant positive correlation is predicted between water temperature and turbidity ( $\mathrm{r}=0.718, \mathrm{p}<0.05)$, that agreed with (Hussainy, 1967), cited from (Authman, 1991) and NHDES (2008), who pointed out that temperature rose when turbidity of water rose and vice versa.

\section{Ammonia}

In raw water, it ranged between the minimum values of 0.03 in Autumn to the maximum value of $0.18 \mathrm{mg} / \mathrm{l}$ obtained in Summer. In filtered water, seasonal variation of Ammonia concentrations were $0.03 \mathrm{mg} / \mathrm{l}$ recorded in Winter and Autumn and 0.05 $\mathrm{mg} / \mathrm{l}$ recorded in Summer and Spring. In treated water, it ranged between the minimum value of $0.00 \mathrm{mg} / \mathrm{l}$ obtained in Autumn to the maximum value of $0.47 \mathrm{mg} / \mathrm{l}$ obtained in Spring, while in tap water, it ranged between 0.05 to $0.54 \mathrm{mg} / \mathrm{l}$ in Autumn and Summer respectively.

Ammonia contamination can also arise from cement mortar pipe linings. Ammonia in water is an indicator of possible bacterial, sewage and animal waste pollution. Ammonia is occasionally found in distribution systems, where chloramine is used as a residual disinfectant. Ammonia can also compromise disinfection efficiency, result in nitrite formation in distribution systems, cause the failure of filters for the removal of manganese and cause taste and odor problems (WHO, 2008). The rise in tap water values is an indication of such process.

\section{Nitrite and Nitrates}

The minimum nitrite value in raw water was $9.91 \mathrm{mg} / \mathrm{l}$ determined during Spring and the maximum value of $16.05 \mathrm{mg} / \mathrm{l}$ recorded in Autumn. In filtered water, nitrite values ranged between 6.46 to $13.93 \mathrm{mg} / \mathrm{l}$ recorded in Spring and Summer respectively. In treated water, the higher value of $14.66 \mathrm{mg} / \mathrm{l}$ was obtained during Winter and the lower value of $5.90 \mathrm{mg} / \mathrm{l}$ was obtained during Spring. In tap water the higher value of $24.61 \mathrm{mg} / \mathrm{l}$ was recorded in Winter and the lower value of $6.31 \mathrm{mg} / \mathrm{l}$ was recorded in Spring.

The seasonal variations of nitrate concentrations varied in the range of 1.54 to $5.48 \mathrm{mg} / \mathrm{l}, 1.33$ to $4.88 \mathrm{mg} / \mathrm{l}, 0.94$ to $5.01 \mathrm{mg} / \mathrm{l}$ and 1.91 to $5.56 \mathrm{mg} / \mathrm{l}$ for raw water, filtered water, treated and tap water respectively, with the higher values recorded in Summer and the lower values obtained during Spring.

The presence of $\mathrm{NO}_{2}$ in tap water in excess is an indication of such incidents. The distribution network of pipes from the water plant to the end users (e.g houses) is considered inadequate, dangerous to human health and destroying the effort and cost of sanitation of water.

As a verification, two tap water samples from different places that have water from the same water plant were measured for No2 and gave different values (4 and 10 $\mathrm{mg} / \mathrm{l}$ ). apparently, the cause was due to variations of infection degrees of the connected pipes for each place.

\section{Phosphate}

The concentrations of phosphates in raw water ranged between 0.11-0.58 mg/l recorded in Autumn and Summer respectively. In filtered water, the value ranged between the lower value $0.08 \mathrm{mg} / \mathrm{l}$ obtained during Autumn the higher value 0.55 $\mathrm{mg} / \mathrm{l}$ recorded in Winter. In treated water, phosphate concentrations varied in the range of 0.01 to $0.51 \mathrm{mg} / \mathrm{l}$ obtained during Summer and Winter respectively while in tap water ranged between $0.26 \mathrm{mg} / \mathrm{l}$ recorded in Autumn and $2.40 \mathrm{mg} / \mathrm{l}$ recorded in Spring. Phosphorus can indicate the presence of septic systems, sewage, animal waste, lawn fertilizer, road and construction erosion, other types of pollution, or natural wetlands and atmospheric deposition (NHDES, 2008). 
The rise of phosphate values in tap water is another indication of mixing water with sewage sources throughout the malfunction or damaged distribution pipes.

\section{Sulphate}

The lowest Sulphate value was recorded in Autumn $21.38 \mathrm{mg} / \mathrm{l}$ in raw water, and the highest value of $27.39 \mathrm{mg} / \mathrm{l}$ was recorded in Summer. In filtered water Sulphate ranged between 25.72 in Winter and $36.99 \mathrm{mg} / \mathrm{l}$ in Summer. In treated water, they ranged between 26.25 in Autumn and $37.33 \mathrm{mg} / \mathrm{l}$ in Summer. In tap water, the lower value of 34.25 observed in Autumn and the higher value of $63.71 \mathrm{mg} / \mathrm{l}$ was noticed in Spring. Tap water values of Sulphate were higher than those of raw water.

In the present work, the seasonal average values were higher during Summer than other seasons. The present results are in disagreement with those of Elewa et al. (1995) who found that the Sulphate was minimum in Summer and maximum during Winter in the Nile water.

Iron

Iron concentrations fluctuated between 0.07 to $0.23 \mathrm{mg} / \mathrm{l}$ recorded in Summer and Autumn in raw water respectively. In filtered water, iron content ranged between $0.00 \mathrm{mg} / \mathrm{l}$ in Winter and $0.11 \mathrm{mg} / \mathrm{l}$ recorded in Autumn and Summer. In the treated water, the values ranged between 0.00 in Winter and $0.11 \mathrm{mg} / \mathrm{l}$ in Autumn. In tap water, the values ranged between 0.05 in Summer and $0.78 \mathrm{mg} / \mathrm{l}$ obtained during Spring.

High concentrations in surface waters can indicate the presence of industrial effluents or run off (APHA, 1998). Iron may also be present in drinking-water as a result of the use of iron coagulants or the corrosion of steel and cast iron pipes during water distribution (Thompson et al., 2007) as was the case in this study. Iron values rose abruptly in tap water exceeding the MPL, in all seasons.

\section{Over All Variation}

On considering the changes in certain number of parameters at different locations and within different seasons, certain trends were found to occur.

Thus, when the change of chloride values in various stages of that Water Plant is considered, conspicuous variation was noticed. Thus, in Winter, chlorides decreased from 39.67 in raw water to 30.5 , but rose again to 36.0 in treated water. This was even farther noticed in tap water samples (41.67). That trend was also noticed during Summer and Autumn.

The change in Sulphate values indicated an ascending trend in each season at the various stages of treatment as well as culminating in tap water. That magnitude reached more than 20\% increase, especially during Spring and Summer. In those seasons, as compared to treated water, the increase in tap water values was $50 \%$ or more.

It is worth to mention that Iron, Nitrates, Ammonia, and Phosphates values were found to increase markedly in tap water. Those parameters decreased in concentration in all seasons at different stages of treatment, to rise abruptly in tap water, with a magnitude of 2 to multiple folds. However, ammonia was represented by an exceptional low values in tap water during Spring.

When the maximum permissible limits were taken into account, a number of the predicted parameters exceeded them in tap water. In certain cases, the values rose above MPL in tap water, although they were safely expressed in treated water. Thus, such marked increase in tap water seasonal values was prominent for nitrite, phosphate and iron, but with the exception of Summer value. It is worth to mention, here, that most of the chemical elements decreased gradually or irregularly as the influent water passes through the different stages of the water treatment process. 
Some of these elements showed higher values at the distributed system, as compared with the preceding steps. This could be interpreted due to one or more of the following:

Damage and rusting of the distributed pipes as in the case of iron oxides.

Flourishing of one of certain bacterial strains such as nitrogen, Sulphates and Phosphorus bacteria. This should be prohibited in order to avoid external contamination.

The results showed that the $\mathrm{pH}$, Chlorides, Alkalinity, Calcium, Dissolved Oxygen, Conductivity, Nitrite, Nitrate, and Ammonia concentrations can be used to predict a wide range of physico-chemical characteristics of water during different seasons.

\section{REFERENCES}

Abd- El Satar, A.M. (1994). Studies on some environmental factors affecting the distribution of some chemical elements and productivity of river Nile at El kanater El Khairia. MSc. Thesis Fac., Sci., Cairo University, Egypt.

Ahmed, Z.A. (1983). Studies on Phytoplankton of the Nile system in upper Egypt. MSc. Thesis , Zool., dep., Fac., Sci., Assuit University, Egypt.

American Public Health Association (APHA) (1985). Standard methods for the examination of water and waste water. American Public Health Association, 15th d, Washington D.C.

American Public Health Association (APHA) (1992). Standard methods for the examination of water and wastewater. American Public Health Association, 18th ed, Academic Press, Washington D.C. 214- 218.

American Public Health Association (APHA) (1995). Standard methods. 19th ed, American Public Health Association, Washington, DC.

American Public Health Association (APHA) (1998). Standard methods for the examination of water and wastewater. 20th ed., Washington, DC.

Authman, M. (1991). Studies on some biological aspects of Bagrus bayad (Family: Bagridae) from Bahr shebeen Canal. MSc. Thesis, Zool., dep., Fac., Sci., Minofeya University, Egypt.

Ayoko, G.; Singh, K.; Balerea, S. and Kokot, S. (2007). Exploratory multivariate modeling and prediction of the physico-chemical properties of surface water and groundwater. J. Hydrology, 336: 115-124.

Birhanu, M. (2007). Assessment of Physico-chemical and Microbiological Quality of Drinking Water at Sources and House hold in Selected Communities of Akakikaliti sub city, Addis Ababa City Administration. M. Sc., Addis Ababa University, School of Graduate Studies.

Elewa A. A. ; Shehata M.B.; Issa Y. M. and El Saatar A. M. (1995). Study on some major anions and cations of the River Nile at El Kanater El Khairia region. Bull. Fac. Sci., Zagazig University, Egypt. 17: 144-165.

Elewa, A. A. and Mahdi, H. (1988). Some Limnological Studies on the Nile water at Cairo, Egypt. Bull. Inst. Oceanogr., fish., A.R.E., 14:141-152.

Elewa, A. and Authman, M. (1991). Limnological studies on Bahr Shebeen El Kom Canal, Minofeya Governorate, Egypt. Fac., Sci., Zagazig University, Egypt.

El-Masry, M.H.; Sadek, O.M. and Mekhemer, W.K. (2004). Purification of raw surface water using electro-coagulation method. Water Air Soil Poll., 158: 373385. 
Haas, C. N. (1999). Disinfection, in R.D. Letterman (ed.), Water Quality and Treatment, 5th ed., AWWA, McGraw-Hill, NY, 14.1-14.49.

Helal, H.A. (1981). Studies on zooplankton of Damietta branch of the River Nile North of Mansoura. Fac., Sci., Mansoura University, Egypt.

Hofkes, E. H. (1983). Small community water supplies: technology of small water supply in developing countries. Wiley, New York.

Hussainy, S.U. (1967). Studies on the limnology and primary production of a tropical lake- India. Hydrobiol, 30: 335-352. IN: Authman, M. (1991). Studies on some biological aspects of Bagrus bayad (Family: Bagridae) from Bahr shebeen Canal. MSc.Thesis , Zool., dep., Fac., Sci., Minofeya University, Egypt.

Långmark, J. (2004). Biofilms and microbial barriers in drinking water treatment and distribution.

Logsdon, G.; Hess, A. and Horsley, M. (1999). Guide to selection of water treatment processes, in Water Quality and Treatment. $5^{\text {th }}$ ed., Letterman, R.D., Ed., McGraw- Hill, New York.

Michael, P. (1986). Ecological methods for field and laboratory investigations. TATA Mcgraw-Hill Publishing company Ltd. New Delhy.

New Hampshire Department of Environmental Services (NHDES) (2008). Interpreting VRAP Water Quality Monitoring Parameters. http://des.nh.gov/organization/divisions/ water/wmb/vrap/index.htm.

Sayyah, S.M.; Elewa, A.A.; Latif, A.F. and Tawfeek, M.F. (1988). The major anions and cations in lake Nasser River Nile water at Aswan, Egypt. Bull. Inst. Oceanogr., fish., A.R.E., 14: 213-226.

Thompson, T.; Fawell, J.; Kunikane, S.; Darryl Jackson, D.; Appleyard, S.; Callan, P.; Jamie Bartram, J. and Kingston, P. (2007). Chemical safety of drinking-water: Assessing priorities for risk management.

United States Environmental Protection Agency (USEPA) (1990). Technologies for Upgrading existing or Designing New Drinking Water Treatment Facilities. Cincinnati.

Welcmme, R.L. (1985). Rivers Fisheries. FAO Fisheries technical Papers.

Wiesner, M. R. and Klute, R. (1997). Properties and measurements of particulate contaminants in water. in J. B. Mcewen (ed.), Treatment Process Selection for Particle Removal, AWWA, IWSA, NY, 35-72.

World Health Organization (WHO) (1996). Guidelines for drinking water quality. $2^{\text {nd }}$ ed, vol. 2, Health criteria and other supporting information,Geneva.

World Health Organization (WHO) (2001). Water health and human rights, World Water Day. Geneva Switzerland: Office of Publications.

World Health Organization (WHO) (2008). Guidelines for drinking-water quality incorporating the first and second addenda. Vol. $1,3^{\text {rd }}$ ed. Geneva.

Zidan, M.A. (1983). Laboratory and field studies on Nile phytoplankton. PhD. Thesis, Zool., depart., Fac., Sci., Assuit University, Egypt. 


\section{ARABIC SUMMARY}

دراسة الخواص الفيزيو كيميائية للماء الداخل والمرشح والمعالج بمحطة شبين الكوم لمياه الثرب.

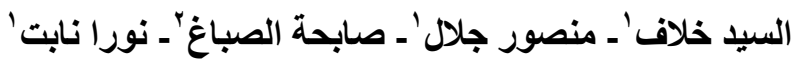

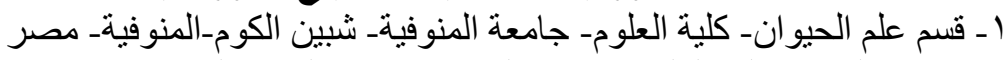

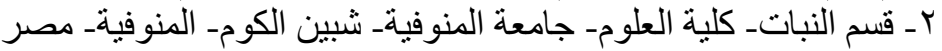

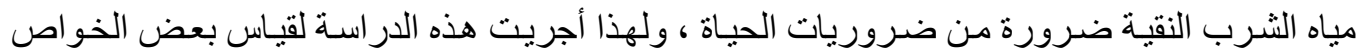

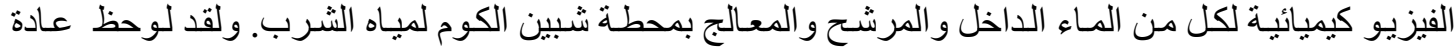

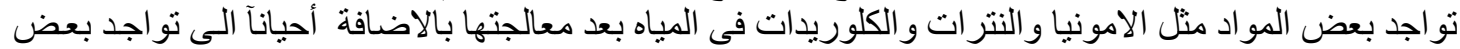

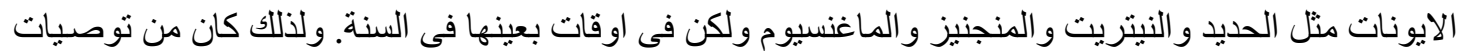

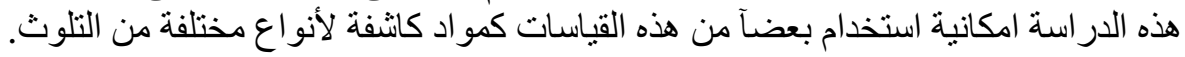

